\title{
Implementasi Bauran Pemasaran Terhadap Pangsa Pasar Melalui Brand Image Di Saat Pandemi Covid 19 Pada Bumdes \\ Feti Fatimah ${ }^{1}$ \\ Universitas Muhammadiyah Jember ${ }^{1}$ fetifatimah@unmuhiember.ac.id
}

\begin{abstract}
Abstrak: Tujuan penelitian ini untuk menganalisis pengaruh bauran pemasaran dan Brand Image terhadap pangsa pasar BUMDes Karya Mandiri Desa Balung Kulon disaat pandemi covid 19, baik secara parsial maupun simultan. Data yang digunakan dalam penelitian ini berupa data primer yang diperoleh melalui penyebaran kuisioner kepada responden, yaitu konsumen Karya Mandiri Desa Balung Kulon yang berjumlah 110 responden. Teknik pengambilan sampel dalam penelitian ini menggunkan teknik random sampling. data, dianalisis menggunakan analisis jalur (path analysis). Hasil penelitian menunjukkan bahwa variabel bauran pemasaran berpengaruh signifikan terhadap Brand Image, Variabel bauran pemasaran berpengaruh signifikan terhadap pangsa pasar, dan Variabel Brand Image berpengaruh signifikan terhadap pangsa pasar .

Kata Kunci: Bauran Pemasaran, Brand Image, Pangsa Pasar, Pandemi Covid 19, BUMDes
\end{abstract}

Dunia bisnis mengalami peningkatan dalam persaingan semakin ketat dan penurunan permintaan selama pandemi Covid 19, sehingga para pelaku bisnis diharuskan untuk meningkatkan kinerjanya agar mampu bersaing, meningkatkan omzet penjualannya serta pangsa pasarnya.

Pangsa Pasar merupakan tujuan pasar yang diprioritaskan. Pangsa pasar sebagai alat untuk menganalisis tujuan pasar suatu produk yang tergantung pada permintaan secara spesifik. Untuk menganalisa tingkat pangsa pasar menggunakan tingkat perilaku keputusan pembelian konsumen. Bauran pemasaran adalah berbagai faktor yang dapat mempengaruhi keputusan pembelian konsumen terhadap suatu produk. Bauran pemasaran ini terdiri dari produk, harga, promosi serta distribusi. .

Bauran pemasaran memiiki pengertian proses penyatuan strategi pemasaran yang disesuaikan terhadap kondisi masing-masing perusahaan yang terstandarisasi dengan produk, harga yang rendah, promosi dan saluran distribusi. ${ }^{1}$ Aspek yang perlu diperhatikan dalam produk adalah kualitas produk. Kualitas produk merupakan pemahaman bahwa produk yang ditawarkan oleh penjual mempunyai nilai jual yang tidak dimiliki oleh produk pesaing. ${ }^{2}$ Sehingga definisi ini dapat dikatakan bahwa seorang penjual telah memberikan kualitas bila penjual telah memenuhi atau melebihi harapan konsumen. Oleh karena itu perusahaan berusaha memfokuskan pada kualitas produk dan membandingkannya dengan produk yang ditawarkan oleh perusahaan pesaing.

Selain kualitas produk, harga adalah faktor yang perlu dipertimbangkan dalam penerapan strategi yang berkaitan dengan penjualan. Harga adalah sejumlah nilai uang yang bersedia dibayar oleh pembeli dan bersedia diterima oleh penjual. ${ }^{3}$ Tujuan dalam penetapan harga jual adalah untuk memperoleh laba yang maksimal, volume 
penjualan yang maksimal, pencitraan produk, atau menstabilkan harga. Penetapan harga yang tepat akan memposisikan produk pada level tertentu di benak konsumen, sehingga menjadi pertimbangan dalam penentuan keputusan pembelian.

Tempat (place) juga memiliki peran yang harus diperhatikan dalam pengambilan keputusan konsumen. Saluran distribusi (place) adalah semua kegiatan yang berhubungan dengan usaha untuk menyampaikan barang-barang hasil produksi suatu perusahaan dari produsen kepada para pembeli atau kepada calon pembeli. ${ }^{4}$

Promosi juga merupakan hal yang harus diperhatikan karena dapat mendorong konsumen untuk membeli produk yang ditawarkan. Untuk mengadakan promosi, setiap perusahaan harus dapat menentukan dengan tepat alat promosi manakah yang dipergunakan agar dapat mencapai keberhasilan dalam penjualan. Tujuan promosi tidak hanya memperkenalkan barang, akan tetapi juga untuk menimbulkan keyakinan dan kesadaran yang dapat menarik dan mempengaruhi konsumen untuk melakukan pembelian. Kegiatan promosi yang tepat diharapkan dapat mempengaruhi keputusan konsumen untuk membeli produk dari perusahaan, sehingga pada akhirnya akan dapat meningkatkan penjualan. Bauran pemasaran ini harus juga diimplementasikan dalam Badan Usaha Milik Desa (BUMDes).

Badan usaha milik desa (BUMDes) merupakan usaha desa yang dikelola oleh Pemerintah Desa dan berbadan hukum. Pemerintah Desa dapat mendirikan Badan Usaha Milik Desa sesuai dengan kebutuhan dan potensi desa. Pembentukan Badan Usaha Milik Desa ditetapkan dengan Peraturan Desa. Kepengurusan Badan Usaha Milik Desa terdiri dari Pemerintah Desa dan masyarakat desa setempat. Demikian juga BUMDes Karya Mandiri Desa Balung Kulon

BUMDes Karya Mandiri Desa Balung Kulon berdiri tahun 2016 jenis bidang usaha adalah usaha Kerajinan, Bank Sampah, Pertenakan dan Pertanian, serta layanan dan jasa umum. Yang sudah dapat berjalan serta menghasilkan pemasukan pada BUMDes adalah usaha kerajinan sedangkan untuk usaha lainnya masih dalam proses merintis. Pelaksanaan usaha kerajinan ini, BUMDes melalukan kerjasama dengan para pengrajin yang berada di desa Balung Kulon.

BUMDes Karya Mandiri Desa Balung Kulon pada awal berdiri yakni tahun 2016 selalu mengalami kenaikan omzet penjualan tetapi semenjak tahun 2019 mengalami penurunan terutama dengan adanya pandemi covid 19. Atas dasar fenomena tersebut maka dilakukan penelitian tentang implementasi bauran pemasaran terhadap pangsa pasar melalui brand image pada BUMDes Karya Mandiri Desa Balung Kulon.

Berdasarkan latar belakang masalah maka permasalahan yang dirumuskan adalah:

1. Apakah bauran pemasaran berpengaruh signifikan terhadap brang image pada BUMDes Karya Mandiri Desa Balung Kulon di saat pandemi covid 19? 
2. Apakah bauran pemasaran berpengaruh signifikan terhadap minat beli pada BUMDes Karya Mandiri Desa Balung Kulon di saat pandemi covid 19?

3. Apakah brand image berpengaruh signifikan terhadap minat beli pada BUMDes Karya Mandiri Desa Balung Kulon di saat pandemi covid 19?

\section{METODE}

Penelitian ini secara explanatory research, yaitu penelitian yang menjelaskan hubungan kausal dan menguji keterkaitan antara beberapa variabel melalui pengujian beberapa hipotesis atau penelitian penjelasan. ${ }^{5}$ Selanjutnya agar tujuan penelitian dapat dicapai, maka data dikumpulkan dengan teknik kuesioner. Populasi adalah semua konsumen BUMDes Karya Mandiri Desa Balung Kulon.

Teknik mengambil sampel secara purposive sampling dengan kriteria pengambilann sampel sebagai berikut:

1. Telah membeli produk BUMDes Karya Mandiri Desa Balung Kulon.

2. Responden yang berumur minimal 17 tahun.

Ukuran sampel tergantung pada jumlah indikator yang digunakan dalam seluruh variabel. ${ }^{6}$ Jumlah sampel adalah sama dengan jumlah indikator dikalikan 5 sampai dengan 10. Pada penelitian ini, jumlah variabel yang diteliti sebanyak satu variabel bebas, satu variabel terikat, dan satu variabel mediasi sehingga total keseluruhan menjadi 22 indikator. Menggunakan 5 kali parameter yang digunakan dalam penelitian untuk sampel. Mengacu pada pendapat ferdinand, maka jumlah sampel dalam penelitian ini di tetapkan sebesar 110 orang responden.

$\mathrm{N} \quad=(5$ sampai $10 \times$ jumlah indikator $)$

$=5 \times 22$ indikator

$=110$

Jenis data yang digunakan dalam penelitian ini adalah kualitatif yang dikuantitatifkan melalui hasil skor kuesioner. Data pada penelitian ini menggunakan data Cross-Section, yaitu data yang dikumpulkan pada waktu tertentu yang dapat menggambarkan keadaan kegiatan pada waktu tersebut. Data penelitian ini mengambil data dalam penelitian ini pada bulan Desember 2020.

Sumber data yang digunakan dalam penelitian ini menggunakan sumber data primer dan sekunder. Yakni data primer ini meliputi hasil respon konsumen (sampel) atas kuesioner terhadap variabel penelitian, karakteristik responden, dan gambaran umum perusahaan. Data sekunder diperoleh dari artikel, jurnal, internet, dokumen, maupun laporan.

Variabel dalam penelitian ini adalah:

1. Variabel independent (X), dalam penelitian ini adalah Bauran Pemasaran. adalah Produk (X1), Harga (X2), Saluran Distribusi (X3), Promosi (X4) Variabel Mediasi (Z) dalam penelitian ini adalah brand image. 
2. Variabel Mediasi (Z), yaitu Mudah Dikenali (Z1), Reputasi (Z2), Selalu Diingat (Z3).

3. Variabel dependen (Y). Pada penelitian ini variable dependen adalah pangsa pasar, dengan mengukur dari minat beli. Minat beli menurut (Ferdinand, 2006) adalah Minat Ekploratif (Y1), Minat Refrensial (Y2), Minat Prefensial (Y3), dan Minat Transaksional (Y4). ${ }^{6}$

Metode pengumpulan data dalam penelitian ini adalah 1) kuisioner yaitu survey menggunakan penyebaran angket pernyataan kepada konsumen, 2) Wawancara, yaitu pengumpulan data dengan cara bertanya secara langsung kepada pemilik/karyawan agar informasi yang diperoleh lebih akurat, 3) Studi Kepustakaan merupakan metode pengumpulan data yang dilakukan dengan membaca buku-buku, literature, jurnal-jurnal, refrensi yang berkaitan dengan penelitian yang dilakukan dan penelitian terdahulu yang berkaitan dengan penelitian yang sedang dilakukan.

Uji Instrumen dalam penelitian ini adalah secara 1) Uji validitas untuk menguji sebuah validitas digunakan teknik product pearson moment yang rumusnya sebagai berikut (Arikunto, 189):

keterangan :

$$
r=\frac{n\left(\sum X Y\right)-\left(\sum X \sum Y\right)}{\sqrt{\left(n \sum x^{2}-\left(\sum x\right)^{2}\right)\left(n \sum Y^{2}-\left(\sum Y\right)^{2}\right)}}
$$

$\mathrm{n}=$ jumlah data observasi

$\mathrm{x}=$ skor tiap pernyataan

$y=$ skor total semua pernyataan

$r=$ koefisien korelasi

Pengambilan keputusan :

1. H0 diterima (valid) jika sig $\leq 0,05(5 \%)$.

2. HO ditolak (tidak valid) jika sig $\geq 0,05(5 \%)$.

2) Uji Reliabilitas, dengan rumus berikut:

Dimana:

$$
\alpha=\frac{(K) \operatorname{Cov} / \operatorname{Var}}{1+(\mathrm{K}-1) \operatorname{Cov} / \operatorname{Var}}
$$

$$
\begin{aligned}
& A=\text { alpha } \\
& K=\text { banyaknya butir pernyataan } \\
& \text { Cov= rerata kovarians diantara butir } \\
& \text { Var= rerata varians dari butir }
\end{aligned}
$$

1. Jika $r$ alpha positif, dan $r$ alpha $\geq r$ tabel, maka variabel tersebut reliabel

2. Jika $r$ alpha positif, dan $r$ alpha $\leq r$ tabel, maka variabel tersebut tidak reliabel.

\section{3) Uji Normalitas Data}

Uji normalitas dengan model kolmogorov-smirnov test dengan menetapkan derajat keyakinan $\alpha$ sebesar $5 \%$. Kriteria pengujian dengan melihat besaran kolmogorov-smirnov test adalah sebagai berikut :

1. Jika signifikansi $\geq 0,05$ maka data tersebut berdistribusi normal. 
2. Jika signifikansi $\leq 0,05$ maka data tersebut tidak berdistribusi normal.

Jika setelah dilakukan uji normalitas data, hasil yang diperoleh menunjukkkan bahwa data tidak berdistribusi normal, maka alternatif yang dapat dilakukan untuk memecahkan masalah ini yaitu dengan menggunakan metode Z-score dan transformasi data dalam bantuk lain seperti logaritma dan akar.

4) Analisis Jalur (path analysis), Untuk menganalisis hubungan kausal antar variabel dan menguji hipotesis dalam penelitan ini secara sistematis, maka analisi alat yang digunakan yaitu analisis jalur (path analysis) dengan menggunakan software spss. Path analysis akan dilakukan estimasi pengaruh kasual antar variabel dan kedudukan masing-masing variabel dalam jalur baik secara langsung maupun tidak langsung.

Berikut diagram jalur maupun koefisien jalur :

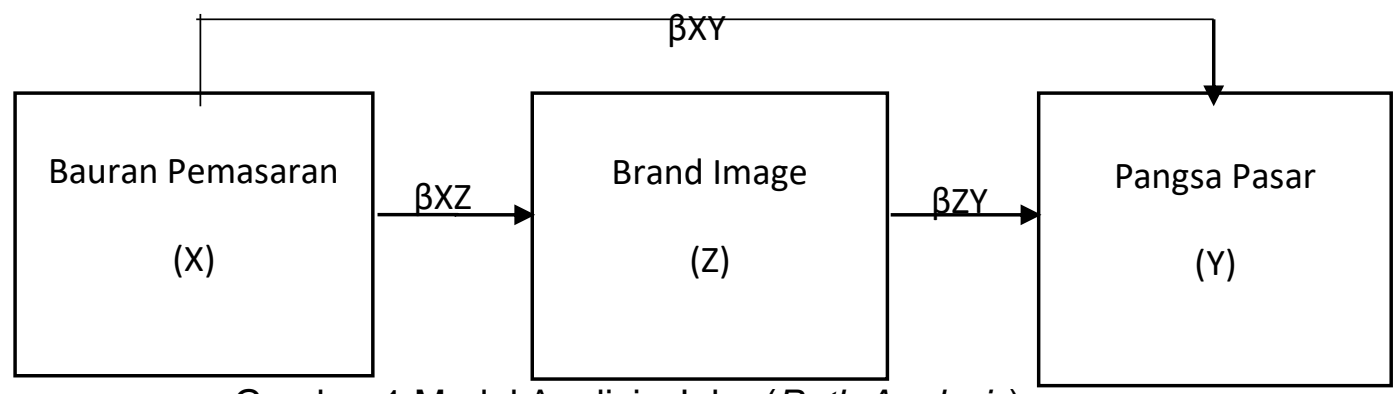

Keterangan:

Gambar 1 Model Analisis Jalur (Path Analysis)

$\beta X Z$ : koefisien jalur pengaruh langsung Bauran Pemasaran terhadap brand image

$\beta X Y$ : koefisien jalur pengaruh tidak langsung Bauran Pemasaran terhadap pangsa pasar.

$\beta Z Y$ : koefisien jalur pengaruh langsung brand image terhadap pangsa pasar.

Uji multikolinearitas diperlukan untuk menguji apakah pada model regresi ditemukan adanya korelasi antar variabel independen. Multikolinearitas terjadi akibat adanya hubungan yang sempurna antar variabel bebas sehingga sulit memisahkan pengaruh tiap-tiap variabel secara individu terhadap variabel terikat.

\section{Uji Heteroskedastisitas}

Pengujiannya dengan cara menggunakan grafik scatterplot, dengan dasar keputusan yakni apabila tidak terdapat pola yang jelas dan titik-titik menyebar diatas dan dibawah angka 0 pada sumbu $\mathrm{Y}$, maka tidak terjadi heteroskedastisitas.

6) Uji Hipotesis (uji t)

Adapun langkah-langkah dalam uji t sebagai berikut :

a. Merumuskan hipotesis 
Ho: $\beta_{1}, \beta_{2}, \beta_{3, \ldots . . \beta n}=0$ (berarti bahwa variabel-variabel bebas secara parsial tidak mempunyai pengaruh terhadap variabel terikat).

Ha: $\beta_{1}, \beta_{2}, \beta_{3, \ldots . . . \beta n} 0$ (berarti bahwa variabel-variabel bebas secara parsial mempunyai pengaruh terhadap variabel terikat).

b. Menentukan tingkat signifikan

Tingkat signifikansi yang diharapkan adalah $\alpha=5 \%$ atau confidence interval sebesar (95\%).

c. Membandingkan nilai t hitung dengan t tabel

Untuk menentukan apakah hipotesis nol diterima atau ditolak dibuat ketentuan sebagai berikut:

1. Apabila $t$ hitung $\geq t$ tabel: Ho ditolak dan Ha diterima. Artinya ada pengaruh antara variabel bebas terhadap variabel terikatnya.

2. Apabila $t_{\text {hitung }} \leq t_{\text {tabel }}$ : Ho diterima dan Ha ditolak. Artinya tidak ada pengaruh antara variabel bebas terhadap variabel terikatnya.

\section{HASIL}

Data deskriptif responden sebagai berikut:

Jumlah responden yang berumur $<21$ tahun sebanyak 18 orang $(16,3 \%), 21$ - 25 tahun sebanyak 28 orang $(25,4 \%), 26-30$ tahun sebanyak 39 orang $(35,4 \%), 31-35$ tahun sebanyak 12 orang $(10,9 \%)$, > 35 tahun sebanyak 13 orang $(11,8 \%)$. Jumlah responden yang berjenis kelamin laki-laki yaitu sebanyak 67 orang (60,9\%), sedangkan yang berjenis kelamin perempuan yaitu sebanyak 43 orang $(39,1 \%)$.

Jumlah responden yang berpendidikan terakhir SMP yaitu sebanyak 12 orang (10,9\%), responden yang berpendidikan terakhir SMA yaitu sebanyak 44 orang $(40 \%)$, responden yang berpendidikan terakhir D3 yaitu sebanyak 23 orang $(20,9 \%)$ dan responden yang berpendidikan terakhir $\mathrm{S1}$ yaitu sebanyak 31 orang $(28,2 \%)$.

Jumlah responden yang berprofesi sebagai mahasiswa / siswa yaitu sebanyak 38 orang (34,5\%), responden yang berprofesi sebagai pegawai negeri yaitu sebanyak 4 orang $(3,6 \%)$, responden yang berprofesi sebagai pegawai swasta yaitu sebanyak 22 orang (20\%), responden yang berprofesi sebagai wiraswasta yaitu sebanyak 41 orang $(37,3 \%)$ dan responden yang berprofesi sebagai lain - lain yaitu sebanyak 5 orang $(4,6 \%)$.

\section{Deskripsi Variabel Penelitian}

Tabel 1 Distribusi Frekuensi Jawaban Responden Variabel Bauran Pemasaran

\begin{tabular}{|c|c|c|c|c|c|c|c|c|c|c|c|}
\hline \multirow{2}{*}{$\begin{array}{l}\text { Nomor } \\
\text { Pernyataan }\end{array}$} & \multicolumn{11}{|c|}{ Jawaban Responden } \\
\hline & 5 & $\%$ & 4 & $\%$ & 3 & $\%$ & 2 & $\%$ & 1 & $\%$ & Total \\
\hline X.1 & 30 & 27.3 & 60 & 54.5 & 18 & 16.4 & 1 & 0.9 & 1 & 0.9 & 110 \\
\hline$X .2$ & 28 & 25.5 & 61 & 55.5 & 17 & 15.5 & 2 & 1.8 & 2 & 1.8 & 110 \\
\hline
\end{tabular}




\begin{tabular}{llllllllllll} 
X.3 & 24 & 21.8 & 77 & 70 & 9 & 8.2 & - & - & - & - & 110 \\
X.4 & 29 & 26.4 & 65 & 59.1 & 9 & 8.2 & 4 & 3.6 & 3 & 2.7 & 110 \\
X.5 & 35 & 31.8 & 59 & 53.6 & 12 & 10.9 & 4 & 3.6 & - & - & 110 \\
X.6 & 21 & 19.1 & 76 & 69.1 & 9 & 8.2 & 4 & 3.6 & - & - & 110 \\
X.7 & 28 & 25.5 & 65 & 59.1 & 13 & 11.8 & 3 & 2.7 & 1 & 0.9 & 110 \\
X.8 & 32 & 29.1 & 45 & 40.9 & 23 & 20.9 & 9 & 8.2 & 1 & 0.9 & 110 \\
X.9 & 34 & 30.9 & 55 & 50 & 17 & 15.5 & 2 & 1.8 & 2 & 1.8 & 110 \\
X.10 & 43 & 39.1 & 58 & 52.7 & 8 & 7.3 & 1 & 0.9 & - & - & 110 \\
\hline Rata-Rata & 30.4 & 27.6 & 62.1 & 56.4 & 13.5 & 12.2 & 3.3 & 3.1 & 1.6 & 1.5 & 110 \\
\hline
\end{tabular}

Berdasarkan data Tabel 1, dapat diketahui bahwa penilaian terbanyak responden terhadap variabel Bauran Pemasaran setuju, yaitu dengan presentasi jawaban pada indikator kualitas produk bagus sebesar $54,5 \%$, indikator Produk mengikuti trend sebesar $55,5 \%$, indikator kemasan produk menarik sebesar $70 \%$, indikator Harga bersaing sebesar $59,1 \%$, indikator terdapat potongan harga bila membeli dalam jumlah banyak sebesar 53,6\%, indikator Produk mudah dijangkau dan ditemukan sebesar $69,1 \%$, indikator Produk selalu tersedia jika dibutuhkan sebesar $59,1 \%$, indikator Promosi yang dilakukan menarik sebesar $40,9 \%$, indikator Pesan lingkungan dalam promosi jelas dan mudah dipahami sebesar $50 \%$ dan indikator Promosi lingkungan yang dilakukan nyata dan jujur sebesar $52,7 \%$. Dari presentase masing-masing indikator diperoleh rata-rata sebesar $56,4 \%$ pada penilaian kriteria jawaban setuju bahwa bauran pemasaran pada BUMDes Karya Mandiri Desa Balung Kulon.

\section{Deskripsi Variabel Brand Image (Z)}

Penilain responden terhadap variabel Brand Image (Z) menurut klarifikasi tingkatan skor dari masing-masing pernyataan Brand Image dijelaskan pada tabel 2.

Tabel 2 Distribusi Frekuensi Jawaban Responden Variabel Brand Image

\begin{tabular}{llllllllllll}
$\begin{array}{l}\text { Nomor } \\
\text { Pernyataan }\end{array}$ & \multicolumn{1}{l}{ Jawaban Responden } \\
\cline { 2 - 12 } & 5 & $\%$ & 4 & $\%$ & 3 & $\%$ & 2 & $\%$ & 1 & $\%$ & Total \\
\hline$Z .1$ & 19 & 17.3 & 69 & 62.7 & 16 & 14.5 & 4 & 3.6 & 2 & 1.8 & 110 \\
$Z .2$ & 11 & 10 & 77 & 70 & 17 & 15.5 & 5 & 4.5 & - & - & 110 \\
$Z .3$ & 13 & 11.8 & 80 & 72.7 & 13 & 11.8 & 3 & 2.7 & 1 & 0.9 & 110 \\
$Z .4$ & 18 & 16.4 & 78 & 70.9 & 10 & 9.1 & 3 & 2.7 & 1 & 0.9 & 110 \\
$Z .5$ & 37 & 33.6 & 58 & 52.7 & 12 & 10.9 & 1 & 0.9 & 2 & 1.8 & 110 \\
Z.6 & 14 & 12.7 & 80 & 72.7 & 11 & 10 & 5 & 4.5 & - & - & 110 \\
\hline Rata-Rata & 18.7 & 17.0 & 73.7 & 67.0 & 13.2 & 12.0 & 3.5 & 3.2 & 1.5 & 1.4 & 110 \\
\hline
\end{tabular}


Berdasarkan data Tabel 2, dapat diketahui bahwa penilaian terbanyak responden terhadap variabel Brand Image setuju, yaitu dengan presentasi jawaban pada indikator Produk mudah dikenali sebesar $62,7 \%$, indikator Terdapat ciri-cirik husus sehingga produk mudah dikenali sebesar $70 \%$, indikator Masyarakat umum mengenal produk sebesar $72,7 \%$, indikator Produk memiliki reputasi yang baik sebesar 70,9\%, indikator Produk diproduksi oleh perusahaan terpecaya sebesar $52,7 \%$ dan indikator Produk mudah diingat sebesar $72,7 \%$. Dari presentase masing-masing indikator diperoleh rata-rata sebesar $67 \%$ pada penilaian kriteria jawaban setuju bahwa Brand Image pada pada BUMDes Karya Mandiri Desa Balung Kulon.

\section{Deskripsi Variabel Pangsa Pasar ( $Y$ )}

Penilain responden terhadap variabel Minat Beli $(Y)$ menurut klarifikasi tingkatan skor dari masing-masing pernyataan Minat Beli dijelaskan pada tabel berikut ini:

Tabel 3 Distribusi Frekuensi Jawaban Responden Variabel Minat Beli

\begin{tabular}{llllllllllll}
\hline $\begin{array}{l}\text { Nomor } \\
\text { Pernyataan }\end{array}$ & \multicolumn{9}{l}{ Jawaban Responden } \\
\cline { 2 - 13 } & 5 & $\%$ & 4 & $\%$ & 3 & $\%$ & 2 & $\%$ & 1 & $\%$ & Total \\
\hline Y.1 & 34 & 30.9 & 61 & 55.5 & 12 & 10.9 & 2 & 1.8 & 1 & 0.9 & 110 \\
Y.2 & 20 & 18.2 & 70 & 63.6 & 15 & 13.6 & 2 & 1.8 & 3 & 2.7 & 110 \\
Y.3 & 23 & 20.9 & 64 & 58.2 & 18 & 16.4 & 5 & 4.5 & - & - & 110 \\
Y.4 & 24 & 21.8 & 68 & 61.8 & 11 & 10 & 6 & 5.5 & 1 & 0.9 & 110 \\
Y.5 & 23 & 20.9 & 69 & 62.7 & 13 & 11.8 & 3 & 2.7 & 2 & 1.8 & 110 \\
Y.6 & 23 & 20.9 & 67 & 60.9 & 16 & 14.5 & 4 & 2.7 & 1 & 0.9 & 110 \\
\hline Rata-Rata & 24.5 & 22.2 & 66.5 & 60.4 & 14.1 & 12.8 & 3.6 & 3.1 & 1.6 & 24.5 & 110 \\
\hline
\end{tabular}

Berdasarkan data Tabel 3, dapat diketahui bahwa penilaian terbanyak responden terhadap variabel Minat Beli setuju, yaitu dengan presentasi jawaban pada indikator Konsumen tetap mencari informasi produk walaupun telah mengenal produk lain sebesar 55,5\%, indikator Konsumen tetap tertarik untuk membeli setelah mendapatkan informasi produk sebesar 63,6\%, indikator Konsumen akan mempromosikan produk kepada teman sebesar $58,2 \%$, indikator Konsumen akan menceritakan pengalaman positif setelah mengkonsumsi produk sebesar $61,8 \%$, indikator Produk adalah pilihan utama sebesar $62,7 \%$ dan indikator Kemasan produk yang menarik konsumen untuk membeli sebesar 60,9\%. Dari presentase masing-masing indikator diperoleh rata-rata sebesar $60,4 \%$ pada penilaian kriteria jawaban setuju bahwa pangsa pasar pada pada BUMDes Karya Mandiri Desa Balung Kulon.

Uji Instrumen

Uji Validitas

Tabel 4 Hasil Uji Validitas

\begin{tabular}{c|c|c|c|c|c}
\hline Variabel & Item & $\mathbf{R}_{\text {tabel }}$ & $\mathbf{R}_{\text {hasil }}$ & Sig & Ket \\
\hline & $\mathrm{X} .1$ & 0.509 & 0.176 & 0,000 & Valid
\end{tabular}




\begin{tabular}{|c|c|c|c|c|c|}
\hline \multirow{9}{*}{ Bauran pemasaran $(X)$} & $X .2$ & 0.577 & 0.176 & 0,000 & Valid \\
\hline & $\mathrm{X} .3$ & 0.502 & 0.176 & 0,000 & Valid \\
\hline & $X .4$ & 0.275 & 0.176 & 0,000 & Valid \\
\hline & $X .5$ & 0.505 & 0.176 & 0,000 & Valid \\
\hline & $X .6$ & 0.630 & 0.176 & 0,000 & Valid \\
\hline & $X .7$ & 0.652 & 0.176 & 0,000 & Valid \\
\hline & $X .8$ & 0.551 & 0.176 & 0,000 & Valid \\
\hline & $X .9$ & 0.481 & 0.176 & 0,000 & Valid \\
\hline & X.10 & 0.291 & 0.176 & 0,002 & Valid \\
\hline \multirow{6}{*}{ Brand Image (Z) } & $\mathrm{Z.1}$ & 0.670 & 0.176 & 0,000 & Valid \\
\hline & $\mathrm{Z} .2$ & 0.626 & 0.176 & 0,000 & Valid \\
\hline & Z.3 & 0.574 & 0.176 & 0,000 & Valid \\
\hline & Z.4 & 0.523 & 0.176 & 0,000 & Valid \\
\hline & Z.5 & 0.498 & 0.176 & 0,000 & Valid \\
\hline & Z.6 & 0.546 & 0.176 & 0,000 & Valid \\
\hline \multirow{6}{*}{ Pangsa Pasar (Y) } & Z.1 & 0.561 & 0.176 & 0,000 & Valid \\
\hline & $\mathrm{Z} .2$ & 0.644 & 0.176 & 0,000 & Valid \\
\hline & Z.3 & 0.626 & 0.176 & 0,000 & Valid \\
\hline & Z.4 & 0.694 & 0.176 & 0,000 & Valid \\
\hline & Z.5 & 0.502 & 0.176 & 0,000 & Valid \\
\hline & Z.6 & 0.522 & 0.176 & 0,000 & Valid \\
\hline
\end{tabular}

Tabel 4 terlihat bahwa korelasi antara masing-masing indikator variabel Bauran Pemasaran (X), Brand Image (Z) dan Pangsa Pasar (Y) menunjukkan hasil yang signifikan dengan nilai $\mathrm{Rh}_{\mathrm{asil}}>\mathrm{Rt}_{\text {abel }}$ dan Sig < 0,05 . Hal ini dapat disimpulkan bahwa semua item pertanyaan dinyatakan valid.

\section{Uji Reliabilitas}

Tabel 5 Hasil Uji Reliabilitas

\begin{tabular}{l|c|c|c}
\hline \multicolumn{1}{c|}{ Variabel Penelitian } & $\begin{array}{c}\text { Cronbach's } \\
\text { Alpha } \\
\text { if item deleted }\end{array}$ & $\begin{array}{c}\text { Standar } \\
\text { realibilitas }\end{array}$ & Ket \\
\hline Bauran Pemasaran (X) & 0,771 & 0,60 & Reliabel \\
Brand Image (Z) & 0,726 & 0,60 & Reliabel \\
Pangsa Pasar (Y) & 0,736 & 0,60 & Reliabel \\
\hline \multicolumn{1}{c|}{ Tabel 5 menunjukkan }
\end{tabular}

Bauran Pemasaran (X), Brand Image (Z) dan Pangsa Pasar (Y). Hasil kuesioner ini telah reliabel karena $r$ alpha yang bernilai lebih besar dari 0,60 . 


\section{Uji Normaliltas Data}

Tabel 6 Hasil Uji Normalitas Data

\begin{tabular}{l|l|l}
\hline Variabel & $\begin{array}{l}\text { Nilai Kolmogorov } \\
\text { Smirnov }\end{array}$ & Keterangan \\
\hline Bauran Pemasaran (X) & 0,200 & Berdistribusi Normal \\
Brand Image (Z) & 0,103 & Berdistribusi Normal \\
Pangsa Pasar (Y) & 0,105 & Berdistribusi Normal \\
\hline
\end{tabular}

Berdasarkan Tabel 6 hasil pengujian pada tabel tersebut, dapat diketahui bahwa nilai variabel Bauran Pemasaran (X), Brand Image (Z) dan Pangsa Pasar (Y) tersebut lebih besar dari 0,05. Sehingga, dapat dinyatakan bahwa data dalam penelitian ini berdistribusi normal.

\section{Analisis Jalur (Path Analysis)}

Hasil analisis jalur disajikan pada gambar sebagai berikut:

Tabel 7 Hasil Path Analysis Variabel

\begin{tabular}{|c|c|c|c|c|}
\hline $\begin{array}{l}\text { Standarized } \\
\text { Jalur }\end{array}$ & Beta & Sig & A & Keterangan \\
\hline $\mathrm{X} \longrightarrow \mathrm{Z}$ & 0,264 & 0,000 & 0,05 & Signifikan \\
\hline$X \longrightarrow Y$ & 0,320 & 0,000 & 0,05 & Signifikan \\
\hline $\mathrm{Z} \longrightarrow \mathrm{Y}$ & 0,235 & 0,021 & 0,05 & Signifikan \\
\hline
\end{tabular}
dijelaskan bahwa antara Bauran Pemasaran (X) dengan Brand Image (Z) memiliki pengaruh yang signifikan. Hal tersebut dapat diketahui dengan hasil nilai signifikan yaitu 0,000 lebih kecil dari $\alpha=0,05$. Jalur kedua antara bauran pemasaran $(\mathrm{X})$ dengan Pangsa Pasar $(\mathrm{Y})$ memiliki pengaruh yang signifikan yaitu sebesar 0,000 lebih kecil dari $\alpha=0,05$. Jalur ketiga antara Brand Image (Z) dengan Pangsa Pasae (Y) memiliki pengaruh yang signifikan yaitu sebesar 0,021 lebih kecil dari $\alpha=0,05$.

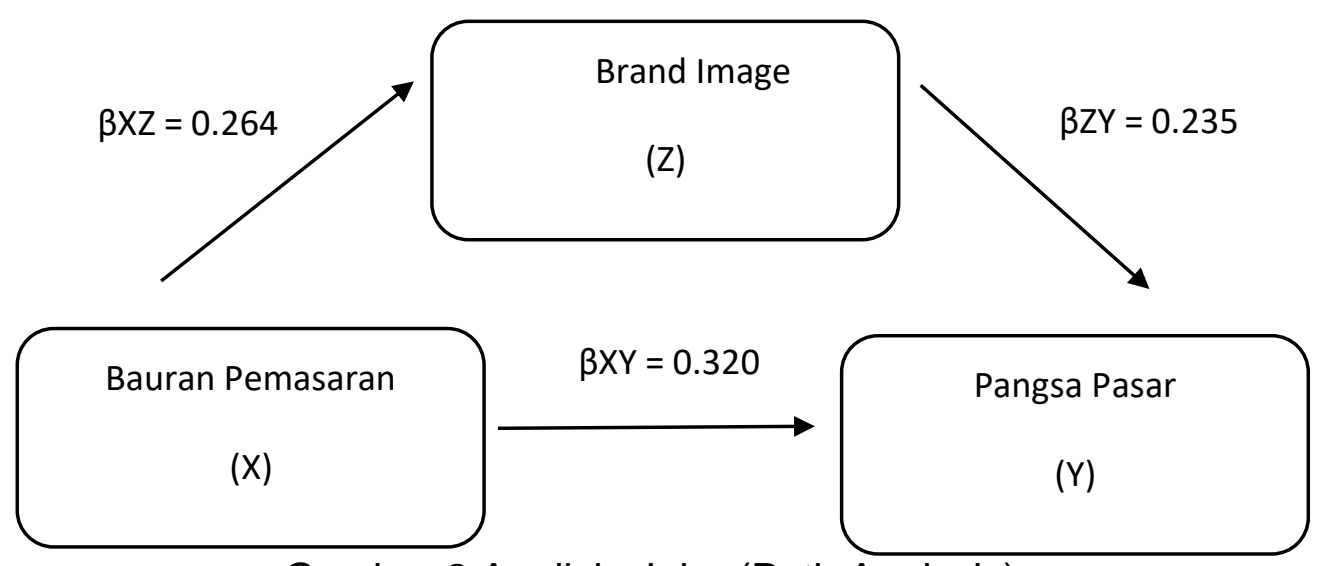

Gambar 2 Analisis Jalur (Path Analysis) 
Keterangan :

$\beta Z$ : Koefisien jalur pengaruh langsung Bauran pemasaran terhadap brand

image

$\beta Y X \quad$ : Koefisien jalur pengaruh langsung Bauran pemasaran terhadap pangsa pasar

$\beta Y Z \quad$ : Koefisien jalur pengaruh langsung brand image terhadap pangsa pasar

Koefisien jalur dihitung dengan membuat persamaan struktutal yaitu persamaan regresi yang menunjukkan hubungan. Model analisis jalur dalam persamaan adalah sebagai berikut:

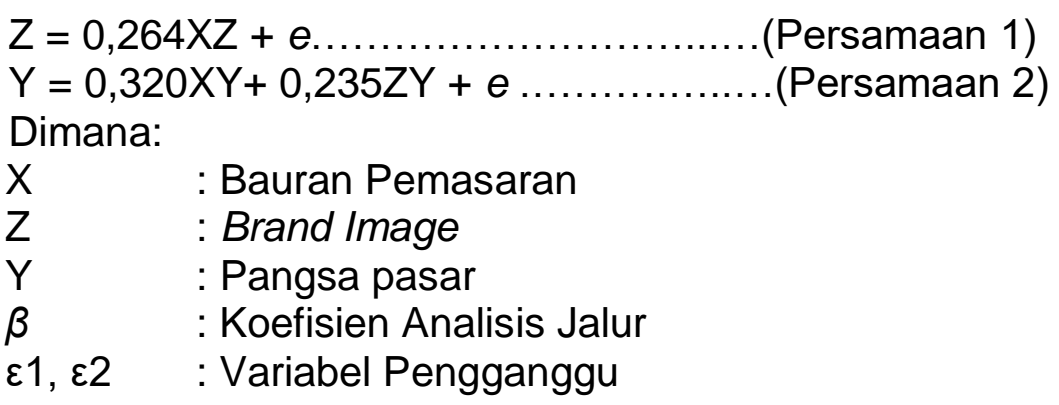

Hasil persamaan struktural koefisien jalur pengaruh bauran pemasaran, Brand Image dan Minat Beli belum dapat dimaknai sebelum dilakukan uji asumsi klasik terlebih dahulu agar terbebas dari multikolinearitas, heteroskedastisitas dan memenuhi asumsi normalitas model.

Uji Asumsi Klasik

Uji Multikolinearitas

Tabel 8 Hasil Uji Multikolinieritas

\begin{tabular}{cccc}
\hline & Model & $\begin{array}{c}\text { Collinearity Statistics } \\
\text { VIF }\end{array}$ & Keterangan \\
\hline $\mathrm{X}$ & $\mathrm{Y}$ & 1,205 & tidak terjadi \\
& & & $\begin{array}{c}\text { multikolinieritas } \\
\text { tidak terjadi } \\
\text { multikolinieritas }\end{array}$ \\
\hline
\end{tabular}

Berdasarkan hasil analisis Collinearity Statistics yang dapat dilihat pada tabel 8 diketahui bahwa model tidak terjadi multikolinieritas. Hal tersebut ditandai dengan nilai VIF dari masing-masing variabel lebih besar dari 0,05 . 


\section{Uji Heteroskedastisitas}

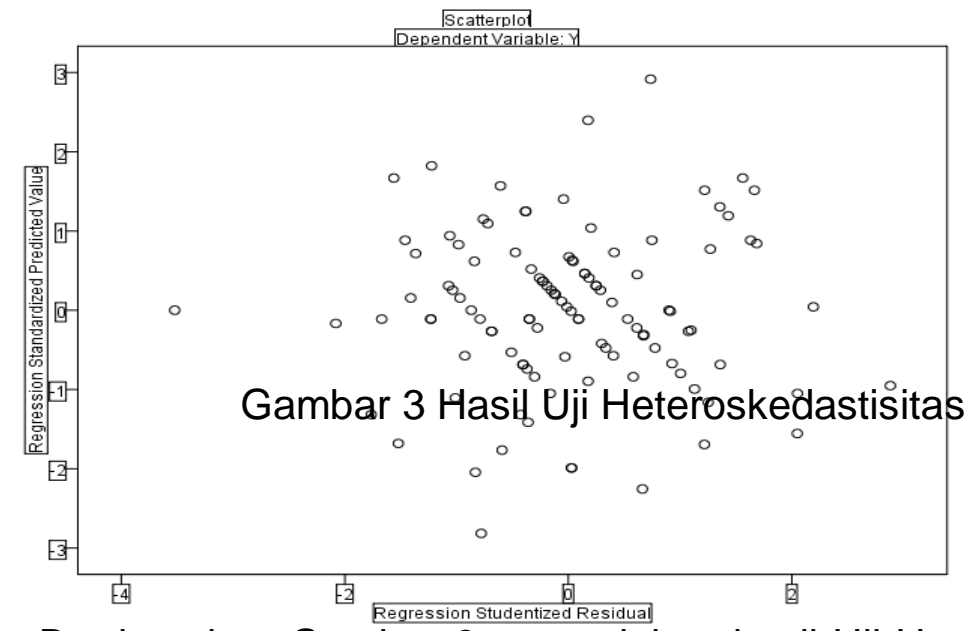

Berdasarkan Gambar 3 menunjukan hasil Uji Heteroskesdasdisitas dengan menggunakan scatter plot yaitu titik-titik yang dihasilkan pada gambar tersebut menyebar dan berbentuk tidak beraturan sehingga dapat dikatakan tidak terjadi heteroskesdastisitas.

\section{Uji Hipotesis}

Uji t

\begin{tabular}{lll}
\hline Hipotesis & A & Sig \\
\hline$X-Z$ & 0,05 & 0,000 \\
$X-Y$ & 0,05 & 0,000 \\
$Z-Y$ & 0,05 & 0,021 \\
\hline
\end{tabular}

Berdasarkan Tabel 9 Uji t hipotesis menunjukkan hasil sebagai berikut:

a. Pengaruh bauran pemasaran Terhadap Brand Image

Berdasarkan Tabel 9 dapat dilihat bahwa Tingkat signifikansi $(\alpha)$ dari variabel bauran pemasaran $(X)$ adalah $0,000<0,05$. Hal ini berarti bauran pemasaran berpengaruh signifikan terhadap Brand Image $\left(\mathrm{H}_{1}\right.$ diterima).

b. Pengaruh bauran pemasaran Terhadap pangsa pasar

Berdasarkan Tabel 9 dapat dilihat bahwa Tingkat signifikansi $(\alpha)$ dari variabel bauran pemasaran $(X)$ adalah $0,000<0,05$. Hal ini berarti bauran pemasaran berpengaruh signifikan terhadap pangsa pasar ( $\mathrm{H}_{2}$ diterima).

c. Pengaruh Brand Image Terhadap pangsa pasar

Berdasarkan Tabel 9 dapat dilihat bahwa Tingkat signifikansi $(\alpha)$ dari variabel Brand Image $(Z)$ adalah 0,021<0,05. Hal ini berarti Brand Image berpengaruh signifikan terhadap pangsa pasar $\left(\mathrm{H}_{3}\right.$ diterima).

\section{Menghitung Jalur}

Perhitungan jalur digunakan untuk menjelaskan tentang pengaruh variabel bauran pemasaran $(\mathrm{X})$, terhadap pangsa pasar $(\mathrm{Y})$ melalui Brand 
Image (Z). Masing - masing jalur harus diuji signifikansinya terlebih dahulu. Apabila setelah diuji terdapat jalur yang tidak signifikan, maka perlu dilakukan metode trimming.

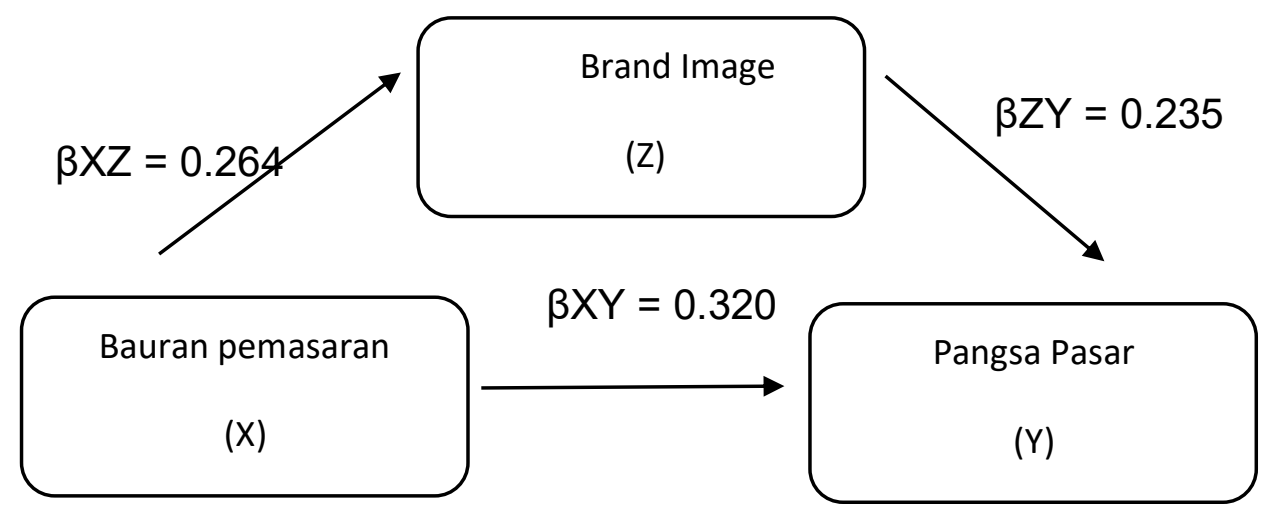

Gambar 4 Analisis Jalur (Path Analysis)

a. Pengaruh Langsung (Direct Effect)

1) Pengaruh langsung variabel bauran pemasaran terhadap Brand Image Konsumen adalah sebesar $26,4 \%$

2) Pengaruh langsung variabel bauran pemasaran terhadap Pangsa pasar adalah sebesar $32 \%$

3) Pengaruh langsung variabel Brand Image terhadap pangsa pasar adalah sebesar $23,5 \%$

b. Pengaruh Tidak Langsung (Indirect Effect)

Pengaruh tidak langsung variabel bauran pemasaran melalui Brand Image terhadap Minat Beli $(0,264 \times 0,235)=0,620$ atau $62 \%$

c. Total Effect

Total effect $: Y \quad X \rightarrow Z \rightarrow Y, 0,320+0,620=$ atau 0,94 atau $94 \%$

\section{Pembahasan}

\section{Pengaruh bauran pemasaran Terhadap Brand Image}

Hasil analisis jalur pada Uji t terhadap hipotesis pertama $\left(\mathrm{H}_{1}\right)$ bahwa bauran pemasaran berpengaruh terhadap Brand Image dengan melihat taraf signifikansinya yaitu sebesar 0,000. Hubungan yang ditunjukkan oleh koefisien regresi adalah positif, artinya semakin baik bauran pemasaran maka Brand Image akan semakin meningkat $\left(\mathrm{H}_{1}\right.$ diterima).

Bauran pemasaran berkembang sejalan dengan naiknya mutu produk BUMDes Karya Mandiri Desa Balung Kulon sehingga Brand Image juga naik.

\section{Pengaruh Bauran Pemasaran Terhadap Pangsa Pasar}

Hasil analisis jalur pada Uji t terhadap hipotesis kedua $\left(\mathrm{H}_{2}\right)$ bahwa bauran pemasaran berpengaruh terhadap pangsa pasar dengan melihat 
taraf signifikansinya yaitu sebesar 0,000 . Hubungan yang ditunjukkan oleh koefisien regresi adalah positif, artinya semakin baik bauran pemasaran maka pangsa pasar akan semakin meningkat $\left(\mathrm{H}_{2}\right.$ diterima).

\section{Pengaruh Brand Image Terhadap Pangsa Pasar}

Hasil analisis jalur pada Uji t terhadap hipotesis ketiga $\left(\mathrm{H}_{3}\right)$ dapat dilihat bahwa Brand Image berpengaruh terhadap pangsa pasar dengan melihat taraf signifikansinya yaitu sebesar 0,021. Hubungan yang ditunjukkan oleh koefisien regresi adalah positif, artinya semakin baik Brand Image maka pangsa pasar akan semakin meningkat $\left(\mathrm{H}_{3}\right.$ diterima).

\section{Kesimpulan}

1. Hasil pengujian analisis jalur atas pengaruh bauran pemasaran terhadap Brand Image pada BUMDes karya mandiri Desa Balung Kulon menunjukkan hubungan yang positif dengan taraf signifikansi sebesar 0,000. Ini membuktikan bahwa di saat pandemi covid 19, semakin tinggi bauran pemasaran perusahaan akan meningkatkan Brand Image perusahaan.

2. Hasil pengujian analisis jalur atas pengaruh bauran pemasaran terhadap pangsa pasar pada BUMDes karya mandiri Desa Balung Kulon menunjukkan hubungan yang positif dengan taraf signifikansi sebesar 0,000. Ini membuktikan bahwa di saat pandemi covid 19, semakin tinggi bauran pemasaran BUMDes akan meningkatkan pangsa pasar.

3. Hasil pengujian analisis jalur atas pengaruh Brand Image terhadap pangsa pasar menunjukkan hubungan yang positif dengan taraf signifikansi sebesar 0,021. Ini membuktikan bahwa di saat pandemi covid 19, semakin tinggi Brand Image BUMDes karya mandiri Desa Balung Kulon akan meningkatkan pangsa pasar.

\section{DAFTAR PUSTAKA}

Kotler, Philip. 2010. Manajemen Pemasaran. Edisi tiga belas Bahasa Indonesia.Jilid 1 dan 2.Jakarta : Erlangga.

Utami, Hesty Nurul \& lqbal Fauzi Akbar Firdaus. 2018. Pengaruh Bauran Pemasaran Terhadap Perilaku Online Shopping: Perspektif Pemasaran Agribisnis. Jurnal Ecodemica, Vol. 2 No. 1 April 2018

Lewis dan Boom. 2005. Service, Quality \& Satisfaction. Edisi ke 3. Yogyakarta: Penerbit Andi

Mursid. 2011. Manajemen Pemasaran. Edisi 1. Cetakan 4. Penerbit Bumi Aksara. Jakarta.

Arikunto. 2006. Prosedur Penelitian Suatu Pendekatan Praktek. Jakarta : PT. Rineka Cipta.

Ferdinand, Augusty. 2006. Metode Penelitian Manajemen. Semarang. CV. Indoprint. 